\title{
The distribution of manganese, iron, nickel, copper and cadmium in the waters of Baffin Bay and the Canadian Arctic Archipelago
}

\author{
J.A. Campbell ab, P.A. Yeats a \\ a Atlantic Oceanographic Laboratory, Bedford Institute of Oceanography, Dart- \\ mouth, Nova Scotia B2Y 4A2, Canada. \\ - Present address: Department of Oceanography, The University of Liverpool.
}

Received $7 / 7 / 81$, in revised form $30 / 11 / 81$, accepted $5 / 12 / 81$.

\section{ABSTRACT}

A detailed study of the distribution of a number of trace elements in Baffin Bay has been carried out. The principal water fluxes have been characterised. For each metal studied, higher concentrations are found in Arctic Ocean surface water advected through Lancaster Sound and Jones Sound than water flowing through Smith Sound. Vertical profile sampling has shown that for each element, surface concentrations are equal to or exceed levels at depth. No surface layer depletion resulting from biological uptake was observed for $\mathrm{Ni}, \mathrm{Cu}$ or $\mathrm{Cd}$. Elevated levels of certain metals from the melting of glacier ice and sea ice, notably $\mathrm{Fe}, \mathrm{Cu}$ and $\mathrm{Cd}$, and the input of metals from the Arctic Ocean via Lancaster and Jones Sounds may mask any uptake in this low production zone. In subsurface waters concentrations of trace metals are constant with depth and at comparable levels to those reported in pelagic areas.

Oceanol. Acta, 1982, 5, 2, 161-168.

\section{RÉSUMÉ}

Distribution du manganèse, du fer, du nickel, du cuivre et du cadmium dans les eaux de la baie de Baffin et de l'archipel arctique canadien.

Une étude détaillée de la distribution de quelques éléments présents à l'état de traces dans la baie de Baffin a été effectuée et les principaux flux marins en ont été caractérisés. Dans chacun des cas, les concentrations retrouvées dans les eaux de surface de l'océan Arctique provenant des détroits de Lancaster et de Jones étaient plus élevées que dans les eaux de surfaces provenant du détroit de Smith. L'étude du profil vertical a d'autre part montré que, pour chaque élément, les concentrations mesurées en surface étaient supérieures ou égales aux concentrations mesurées aux différentes profondeurs. Aucune dégradation, due à l'activité biologique, au niveau de la couche superficielle, n'a été observée pour $\mathrm{Ni}, \mathrm{Cu}$ ou $\mathrm{Cd}$. Les niveaux élevés de concentrations de certains métaux provenant de la fonte des glaciers et des glaces flottantes, notamment pour $\mathrm{Fe}, \mathrm{Cu}$ et $\mathrm{Cd}$, et l'apport en métaux de l'océan Arctique par les détroits de Lancaster et de Jones ont toutefois pu masquer les effets de l'activité biologique dans cette zone de faible production. Les concentrations en métaux présents à l'état de traces dans les eaux sous-jacentes ne variaient pas avec la profondeur et étaient de niveau comparable aux concentrations mesurées dans les zones pélagiques.

Oceanol. Acta, 1982, 5, 2, 161-168.

\section{INTRODUCTION}

In recent years, extensive study of the marine geochemistry of a number of trace elements, notably manganese, nickel, copper, zinc and cadmium, has been carried out (Bender, Gagner, 1976; Boyle et al., 1976; Sclater et al., 1976; Bender et al., 1977; Boyle et al., 1977; Bruland et al., 1978 a, b; Moore, 1978; 
Bruland et al., 1979). Improvements in sample collection techniques and analytical capability have led to a general acceptance of mean trace metal levels in ocean waters lower than previous estimates (Spencer et al., 1970; Riley, Taylor, 1972). Of principal interest in these investigations has been the vertical distribution of the elements in the ocean. Depth profiles for $\mathrm{Ni}, \mathrm{Cu}, \mathrm{Zn}$ and $\mathrm{Cd}$ display concentration depletion in the upper mixed layer and increasing concentration with depth (Sclater et al., 1976; Moore, 1978; Bruland et al., 1978 $a, b)$. Such trends have been interpreted in terms of biological uptake in the euphotic zone and subsequent regeneration at depth with several striking correlations between metal concentration and nutrients to support this theory.

Large scale spatial variability in trace metal concentrations has also been reported. Bewers et al., (1976) have noted significant differences in trace metal concentrations for distinct water regimes in the northwest Atlantic Ocean. Moreover, concentrations of $\mathrm{Ni}$ and $\mathrm{Cu}$ in deep waters in the Pacific are generally higher than at depth in the Atlantic (Sclater et al., 1976; Moore, 1978). On the other hand dissolved manganese concentrations are generally lower in the deep Pacific than in the deep Atlantic (Bender et al., 1977). Spatial variability in the Atlantic Ocean was also observed in this latter study.

While most of the cited work has focussed on the Pacific and Atlantic Oceans, with further limited study in the Indian Ocean (Danielsson, 1980) very few data exist for the Arctic Ocean (Burrell et al., 1968; Burrell, 1971). Very recently, Dyrssen et al. (1981) and Moore (1981) reported metal profiles for an Arctic Ocean station north of Franz Joseph Land and an ice station over the Lomonosov Ridge. We report here a study of trace metal distributions in the Canadian Eastern Arctic, principally Baffin Bay. In addition to vertical profile sampling, we have attempted to establish the trace metal content of the principal water masses of the area.

\section{AREA OF STUDY}

Baffin Bay forms a deep, enclosed depression between the Canadian Arctic Archipelago and Greenland. The maximum depth is approximately 2300 to $2400 \mathrm{~m}$. Exchange of water with the Atlantic Ocean to the south is restricted by a sill in Davis Strait at a depth of $\approx 700 \mathrm{~m}$. Furthermore, sill depths of 100 to $150 \mathrm{~m}$ in Lancaster Sound and Jones Sound and $200 \mathrm{~m}$ in Smith Sound constrain the exchange of Arctic Ocean water with that in Baffin Bay. The water circulation pattern in Baffin Bay (Collin; 1966) is composed of the West Greenland Current that passes northward through eastern Davis Strait and the Baffin Current (also known as the Baffinland or Canadian Current) moving southward along the coast of Baffin Island. The West Greenland Current is relatively temperate and saline $\left(T=3-4^{\circ} ; \mathrm{S}=34.5 \%\right.$ ) as it carries with it waters from the East Greenland Current that continues westward around Cape Farewell and from the com- paratively warm Irminger Current that impinges on the south east coast of Greenland. The Baffin Current is formed from the outflow of cold, less saline Arctic water from the channels of the Archipelago and the northern cooled remnant of the West Greenland Current. The predominant flow through the Archipelago is in easterly and southerly directions. Low temperature, low salinity water characteristic of outflowing Arctic Ocean surface water ( $\mathrm{T}=-1.8$ to $-1^{\circ} ; \mathrm{S}=32.5$ to $33.5 \%$ ) flows eastwards through Lancaster and Jones Sounds, while more saline Arctic water is advected southward through Smith Sound from the Lincoln Sea.

Both sea ice and glacier ice play an important part in the physical oceanography of Baffin Bay. With the exception of south east Baffin Bay and the North Water Polynya which are both largely ice free, the surface of Baffin Bay and the Canadian Archipelago supports a more or less continuous mantle of sea ice throughout at least six months of the year. Moreover, while there are no major rivers draining into Baffin Bay, there is a considerable contribution of fresh water from icebergs calved from numerous glaciers. Murray (1968) has reported that $70 \%$ of all icebergs calved in Baffin Bay remain in the embayment, presumably gradually melting through succeeding summers.

The water column in central Baffin Bay is composed of four water masses identified by the vertical distribution of temperature and salinity (Riis-Carstensen, 1936). In summer the surface water is characterised by a wide range of properties with temperatures from -1 to $+5^{\circ}$ and salinities between 30.0 and $32.7 \%$. Underlying the surface layer, cold Arctic water is recognised by a temperature minimum of -1 to $-1.8^{\circ}$ and salinity of $33.7 \%$. Below $300 \mathrm{~m}$ is a warm water layer, a mixture of Labrador Sea Intermediate Water and the overlying cold layer $(T=0$ to $2^{\circ}, \mathrm{S}=34.4 \%$ ). Deep water is found between 1200 and $2100 \mathrm{~m}$ and is identified by temperature of $-0.5^{\circ}$ and salinity of $34.45 \%$. The mechanism of formation of this deep water mass is uncertain and several hypothesis have been set out (Sverdrup et al., 1942; Bailey, 1956; Redfield, Friedman, 1969; Sadler, 1975).

\section{SAMPLE COLLECTION AND ANALYTICAL TECHNIQUES}

Samples were collected during Bedford Institute cruises 77-024 and 78-026 aboard CSS Hudson during August and September, 1977 and September, 1978. Station locations for both cruises are shown in Figure 1. Station 77-19 is situated in the deepest part of Baffin Bay and was sampled at high density to study the extent of hydrographic and biological modification of the metal profiles. The other stations are located in the four entrances to Baffin Bay with the intention of sampling the various water masses flowing into and out of the Bay. On the 1977 cruise, modified twelve litre Niskin samplers were employed (Bewers et al., 1974). For the 


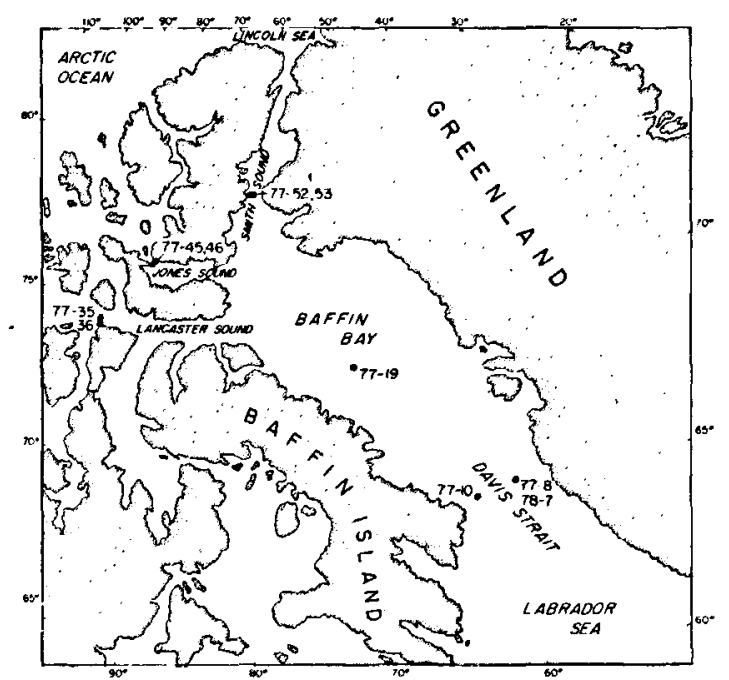

Figure 1

The Canadian Eastern Arctic and Baffin Bay with oceanographic station locations.

second cruise in 1978, Go-Flo sampling bottles, also of twelve litre capacity were used. In both instances bottles were hung upon a stainless steel hydrowire which terminated with an epoxy-coated lead weight. Brass messengers were used to trip bottles on each hydrocast. Prior to each cruise Niskin and Go-Flo samplers were thoroughly washed with deionised (SQ) water and stored in sealed polyethylene bags until required. Sample collection, filtration and storage procedures have been reported previously (Bewers et al., 1976).

Metal concentrations were determined by chelation/solvent extraction procedures (Brooks et al., 1967) and flameless atomic absorption spectrometry using a Perkin-Elmer 403 spectrometer, HGA 2100 graphite furnace with AS-1 autosampler attachment and deuterium arc background correction. $\mathrm{Fe}, \mathrm{Ni}, \mathrm{Cu}$ and $\mathrm{Cd}$ were extracted into 4-methyl pentan-2-one (MIBK) at $\mathrm{pH}=4$ as ammonium pyrrolidine dithiocarbamate complexes, while Mn was extracted, also into MIBK, at $\mathrm{pH}=9.2$ as an 8 -hydroxy quinoline complex. Chemical preconcentration procedures were carried out in a laminar air flow hood and in the laboratory a minimum of metal parts was used, these wherever possible being coated with an epoxy paint. Furthermore, the air in the laboratory was constantly filtered to minimise dust contamination (HEPA filter with $99.97 \%$ efficiency for $0.3 \mu \mathrm{m}$ particles).

Both filtered and unfiltered samples were analysed for each element, although significant differences between filtered and unfiltered concentrations were only observed for iron and manganese. We have assumed here that analyses of filtered samples provide a measure of "dissolved" metal and that analyses of unfiltered samples provide a measure of "dissolved" and "particulate" metal. The "particulate" metal measurements represent predominantly exchangeable metal and near surface metal, soluble at the sample storage $\mathrm{pH}$ of 2.

Ice samples were collected from a launch and stored frozen in double polyethylene bags. Before analysis, the ice sample was broken while still in the bags and a piece of ice from the center of the sample was selected for analysis. The ice was melted and a portion of the meltwater filtered through a $0.4 \mu \mathrm{m}$ Nuclepore filter. Trace metal concentration were determined in two ways. First by extraction following the methodology for seawater and secondly by direct injection of the meltwater into the graphite fumace. The direct injection method gives a more complete analysis of the particulate metals.

\section{LIMITS OF DETECTION AND ANALYTICAL PRECISION}

While it is possible to determine detection limits in terms of signal to noise ratio and minimum absorbance measurements, these methods do not include inherent uncertainty in analytical techniques pertaining to trace metal assay. Thus, in determining detection limits, the approach of Strickland and Parsons (1960) has been applied where the limit of detection is defined as three times the analytical standard deviation of samples close to the detection limit. In addition, replicate analyses on a large volume seawater sample provided an assessment of overall analytical precision. The estimate does not, however, include errors entailed in sample collection. Detection limits and the results of the replicate study are given in Table 1. In columns 1 and 2 mean elemental concentrations of a series of replicate analyses on a bulk sample and associated coefficients of variation are shown. The laboratory detection limit in column $\mathbf{3}$ is based on the above definition.

Table 1

Analytical precision and detection limits

\begin{tabular}{llll}
\hline Element & $\begin{array}{l}\text { Mean } \\
\text { concentration } \\
\mu \mathrm{g} . \mathrm{I}^{-1}\end{array}$ & $\begin{array}{l}\text { Coefficient } \\
\text { of } \\
\text { variation \% }\end{array}$ & $\begin{array}{l}\text { Detection } \\
\text { limits } \\
\mu \mathrm{g} . \mathrm{I}^{-1}\end{array}$ \\
\hline Mn (total) & - & - & 0.04 \\
Mn (dissolved) & $\mathbf{0 . 1 3}$ & $\mathbf{1 2}$ & 0.03 \\
Fe (total) & $\overline{1.03}$ & $\overline{30}$ & 0.52 \\
Fe (dissolved) & $\mathbf{N i}$ & 13 & 0.25 \\
$\mathrm{Ni}$ & 0.21 & 14 & 0.04 \\
$\mathrm{Cu}$ & 0.21 & 18 & 0.06 \\
$\mathrm{Cd}$ & 0.059 & 18 & 0.020 \\
\hline
\end{tabular}

* based on definition of Strickland and Parsons (1960)

\section{RESULTS AND DISCUSSION}

Results of trace element determinations of sea water samples are presented in Table 2. Metal and particulate matter concentrations in sea ice and glacier ice are given in Table 3.

The data presented in Table 2 display a clear pattern of spatial variability that is entirely consistent with the water circulation in this region. The highest metal concentrations are observed in the Arctic Ocean surface water entering Baffin Bay through Lancaster (stations 77-35, 36) and Jones Sounds (stations 77-45, 46). The 
Davis Strait. This water (station $77-10<200 \mathrm{~m}$ ) has generally intermediate metal concentrations.

Probably the most interesting feature of the spatial distribution is the elevated levels of all studied metals in the waters of the western channels of the Canadian Archipelago compared to water coming through Smith Sound. At present, the reason for this distribution is not known. A similar pattern has been found for silicate, phosphate, and nitrate (Jones, Coote, 1980); concentrations of the nutrients are higher in Jones and Lancaster Sounds than in Smith Sound. Jones and Coote (1980) have interpreted the distribution in terms of an input of nutrient-rich water from the Bering Sea and the surface circulation pattern in the Arctic Ocean. Although the water advected through Bering Strait is probably also relatively high in trace metals, the proposed relationships between metals and nutrients (Sclater et al., 1976; Moore, 1978; Bruland et al., 1978) would predict considerably smaller differences between $\mathrm{Ni}, \mathrm{Cu}$ and $\mathrm{Cd}$ levels for the two Arctic surface water types than are actually observed. The most probable source of water enriched in trace elements is river input from North American and Asian landmasses to the Canadian Basin of the Arctic Ocean. Mapping of surface currents in the Arctic Ocean has generally shown a drift from West to East over the north pole with a clockwise gyre in the Canadian Basin (Collin, Dunbar, 1964; Coachman, Aagaard, 1974). From the nutrient studies, Jones and Coote (1980) have proposed that the clockwise gyre in the Canadian Basin extends as far as the Peary Channel in the Queen Elizabeth Islands (Canadian Archipelago) but not as far as the Lincoln Sea which is connected to Baffin Bay through Smith Sound. The limited data for trace metals in the Arctic Ocean indicates that at the Lorex site north of Ellsmere Island (Moore, 1981), trace metal concentrations are considerably higher than those observed north of Franz Joseph Land (Dyrssen et al., 1981). Therefore, although river discharge and subsequent dispersion and dilution of metal burden of rivers draining into the Arctic Ocean are poorly documented, fluvial input to the surface waters of the Canadian Basin of the Arctic Ocean is the most plausible source for the elevated concentrations of trace metals in the western channels of the Canadian Archipelago.
It is evident from the general distribution that concentrations in the outflowing Baffin Current are intermediate between those of the high (through Lancaster and Jones Sounds) and low concentration (Smith Sound and West Greenland Current) inputs. The extent to which processes occurring within Baffin Bay affect the levels in the Baffin Current can be estimated by constructing a trace metal budget for the Bay.

In constructing a water budget for Baffin Bay the following assumptions have been made. Most estimates of water transports have been derived from data accumulated during summer months and these have been accepted as representative of year round conditions. Only circulation in the surface and intermediate depth layers (down to $1200 \mathrm{~m}$ ) is considered. Although the flow limiting sill in Davis Strait occurs at $700 \mathrm{~m}$ Labrador Sea Intermediate Water is found down to $1200 \mathrm{~m}$. As the mechanism of deep water (below 1200 m) formation is thought to be slow, processes related to deep water exchange have been neglected. Although the dominant direction of net water flow through the Canadian Archipelago is eastwards for Lancaster and Jones Sounds and southward for Smith Sound, Bailey (1957) and Muench (1971) have recorded anomalous flow opposite to the established pattern for both Jones and Smith Sound. Such events appear to be transient and are not considered here. Inputs of meteoric water, glacier-ice and sea-ice meltwater will be small compared to the principal water fluxes and have been neglected. Finally, there are no major rivers draining directly into Baffin Bay and consequently river inputs are not considered.

Transport data for the principal water fluxes in Baffin Bay show reasonable consistency. Water mass data used in the metal budget calculation shown in Table 4 have been chosen to give conservation of mass and salt. The trace element fluxes are calculated by multiplying the average metal concentrations in the appropriate water masses by the water transports. The fluxes of $\mathrm{Fe}$, $\mathrm{Ni}, \mathrm{Cu}$ and $\mathrm{Cd}$ into Baffin Bay are balanced by the efflux via the Baffin Current. Processes occurring within the Bay thus have little effect on the budgets for these metals. Only total manganese shows a small net influx that is significant compared to the precision. Settling of

Table 4

Trace metal flux estimates for Baffin Bay

\begin{tabular}{|c|c|c|c|c|c|c|c|}
\hline & \multicolumn{2}{|c|}{ Water } & \multicolumn{5}{|c|}{ Metal transport $\left(10^{6} \mathrm{~kg} \mathrm{yr}^{-1}\right)$} \\
\hline & $\begin{array}{l}\text { Salinity } \\
\% \%\end{array}$ & $\begin{array}{l}\text { Transport* } \\
10^{16} \mathrm{~kg} \mathrm{yr}^{-1}\end{array}$ & $\mathrm{Mn}$ & $\mathrm{Fe}$ & $\mathrm{Ni}$ & $\mathrm{Cu}$ & $\mathrm{Cd}$ \\
\hline $\begin{array}{l}\text { Eastern Davis St. } \\
\text { (West Greenland Current) }\end{array}$ & 34.5 & 3.5 & $3.5(0.10)$ & $38(1.1)$ & $7.3(0.21)$ & $8.4(0.24)$ & $1.1(0.03)$ \\
\hline Smith Sound & 33.5 & 2.1 & $4.0(0.19)$ & $27(1.3)$ & $4.6(0.22)$ & $3.8(0.18)$ & $0.8(0.04)$ \\
\hline Jones Sound & 32.7 & 0.8 & $3.0(0.37)$ & $14(1.7)$ & $2.2(0.28)$ & $2.3(0.29)$ & $0.4(0.05)$ \\
\hline Lancaster Sound & 32.7 & 1.6 . & $4.8(0.30)$ & 27 (1.7) & $4.5(0.28)$ & $4.8(0.30)$ & $1.0(0.06)$ \\
\hline $\begin{array}{l}\text { Western Davis St. } \\
\text { (Baffin Current) }\end{array}$ & & & & & & & \\
\hline $\begin{array}{l}\text { (Baffin Current) } \\
\text { Total influx }\end{array}$ & 33.6 & 7.8 & $12.5(0.16)$ & $94(1.2)$ & $17.2(0.22)$ & $19.5(0.25)$ & $3.1(0.04)$ \\
\hline $\begin{array}{l}\text { Total influx } \\
\text { Total efflux }\end{array}$ & & $\begin{array}{l}8.0 \\
7.8\end{array}$ & $\begin{array}{l}14.0 \\
12.5\end{array}$ & 94 & 17.2 & 19.5 & \\
\hline Net influx & & 0.2 & 2.1 & 12 & 1.4 & -0.2 & 0.2 \\
\hline
\end{tabular}

Figures in parentheses are average concentrations $\left(\mu \mathrm{g}^{-1}\right)$ in the indicated water masses.

* Water transport data are taken from Collin and Dunbar (1964) except for Smith Sound data from Sadler (1975). 
particulate matter within Baffin Bay would probably accounts for the removal of this excess manganese.

The residence time for all water masses down to the bottom of the intermediate depth layer $(=1200 \mathrm{~m}$ ) based on the flux date presented in Table 4 is about 10 years. Trace metal residence times can be calculated using the metal input data in Table 4 and results from station 19 to estimate the metal inventory for the Bay. The resulting residence times for $\mathrm{Ni}, \mathrm{Cu}$ and $\mathrm{Cd}$ of between 9 and 10 years are equal to the water residence time. Manganese and iron give slightly longer residence times of 12-14 years. We can conclude therefore, on the basis of these rather rough budget calculations, that the metal distributions are controlled predominantly by the physical oceanography. Geochemical processes occurring within the Bay can have only a minor effect on the metal distributions.

Trace element depth profiles for a station at the deepest part of Baffin Bay (station 77-19, Table 2) are shown in Figure 2. Salinity and temperature depth profiles (Fig. $3 a$ ) are consistent with the established oceanographic record outlined above. Also shown are depth profiles for the major nutrients, silicate, phosphate and nitrate (Fig. $3 \mathrm{~b}$ ). These latter profiles clearly show depletion in the surface layer, related to biological uptake, with regeneration at depth. In con-

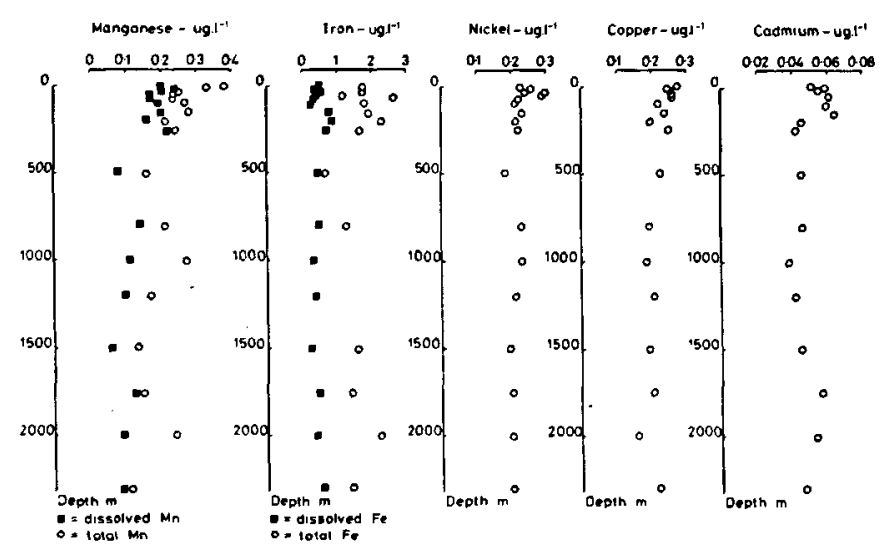

Figure 2

Vertical profiles for iron, manganese, nickel, copper and cadmium in central Baffin Bay at station 77-19.
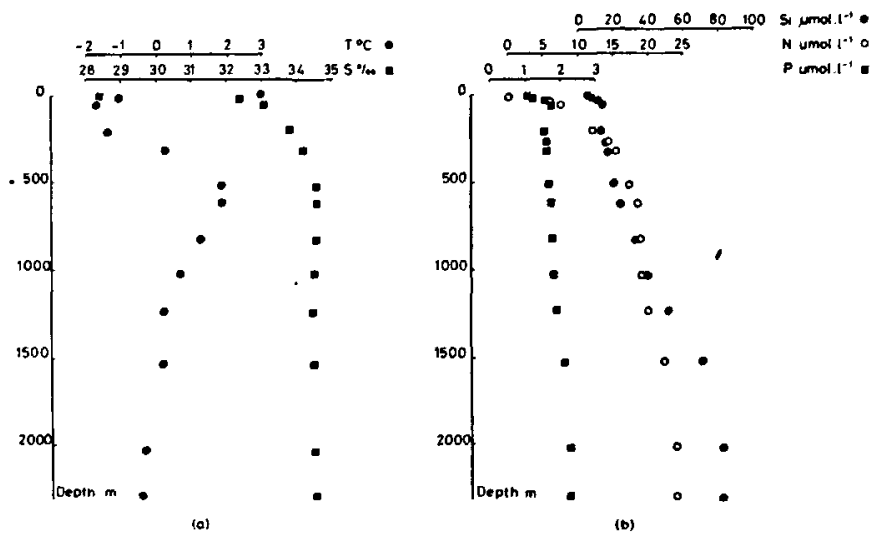

Figure 3

Vertical profiles for (a) salinity, temperature and (b) nutrients in central Baffin Bay at station 77-19. trast to investigations in pelagic areas, surface trace metal concentrations generally exceed those found at depth, with no metal-nutrient correlations being evident. The vertical distribution of the metals studied may be appropriately discussed in terms of the water mass characterisation suggested by Riis-Carstensen (1936) given earlier.

The upper $200 \mathrm{~m}$ comprises a thin surface layer of variable temperature and salinity $(\approx 30 \%$ ) overlying an admixture of cold Arctic surface waters advecting through Lancaster, Jones and Smith sounds $\left(T<1^{\circ}\right.$, $\mathrm{S}=33.5 \%$ o). In this layer metal concentrations are greater than at depth as a direct result of the high metal input through Lancaster and Jones sounds. Extensive biological removal of nutrients is restricted to the top $30 \mathrm{~m}$ of the water column by an intense seasonally induced thermocline. Below this shallow thermocline, the nutrient maxima indicate the core of the Arctic surface layer admixture. Total manganese is the only metal that shows a distinct concentration gradient across the thermocline. Otherwise the metal concentrations are constant throughout the top $200 \mathrm{~m}$. Total iron shows more scatter than the other metals probably as a result of variations in the particulate matter concentrations.

Baffin Bay Intermediate Water, a warm layer extending from 300 to $1200 \mathrm{~m}$, originating in the Labrador. Sea and supplied by the West Greenland Current, occurs below the surface layer. In this layer, while nutrient concentrations increase steadily, trace metal levels are generally invariant at concentrations somewhat lower than observed in the overlying water. The metal levels in the intermediate water reflect the low metal concentrations found in the West Greenland Current source water and are generally comparable to those found in the North Atlantic Ocean (Bender, Gagner, 1976; Bender et al., 1977; Moore, 1978) or the eastern Arctic Ocean (Dyrssen et al., 1981).

Deep water, presently of uncertain origin, is found below $1200 \mathrm{~m}\left(\mathrm{~T}=0.5^{\circ} ; \mathrm{S}=34.45 \%\right.$ \% $)$. Trace metal levels in the deep water are more or less invariant and similar to the levels measured in the overlying intermediate water although slight discontinuities between 1200 and $1500 \mathrm{~m}$ may be evident for some metals. Silicate, phosphate and nitrate profiles, however, show a distinct increase at the intermediate water-deep water boundary. While deep phosphate and nitrate concentrations are consistent with levels at comparable depths in the North Atlantic (Stefansson, 1968), silicate concentrations are far in excess of typical Atlantic Ocean values (Mann et al., 1974).

In pelagic areas, is has generally been found that surface waters are depleted in certain trace metals (e.g. Ni and $\mathrm{Cd}$ ) with respect to deeper water due to involvement of these elements in biological cycling. At station $77-19$, nutrient depletion is observed in the top $30 \mathrm{~m}$ of the water column but depletion of metals is not observed. The apparent excess of trace metals suggests a source of metals sufficiently large to mask any losses via biological uptake. These inputs will come predominantly from two sources; the advection of surface water high in trace metals through Lancaster and Jones Sounds and the melting of ice. Sea ice meltwater has 
been shown to contribute as much as $15 \%$ of the surface water in Baffin Bay (Tan, Strain, 1980). Direct aeolian input is unlikely to be important since precipitation in this area is small and the Bay is ice-covered for much of the year. There are no large rivers draining directly into Baffin Bay so fluvial input of metals is also unlikely to be important. Thus melting of glacier ice and sea-ice should constitute the major source of freshwater to the surface waters of Baffin Bay.

Metal analysis of glacier ice and sea ice samples collected in northwest Baffin Bay off Bylot Island (Table 3) yield concentration of metals in excess of the levels observed in surface waters (Table 2). The difference is most marked for $\mathrm{Fe}_{t}$ and $\mathrm{Cu}$. High particulate concentrations, primarily of freshly weathered mineral fragments, were found in both glacier ice and sea ice. In the latter, the particulate load is perhaps surprising and suggests that the ice floe that was sampled had formed in shallow water or had been rafted across a beach at some previous time. Thus the sea-ice data presented here may be atypical of much of the sea ice in Baffin Bay. With the exception of iron, which is predominantly associated with particles, the major fraction of the metals was found in the dissolved phase (i.e. was analyzed as dissolved in meltwater after filtration through a $0.4 \mu \mathrm{m}$ Nuclepore filter). Since the sea-ice meltwater content of the surface water of station 77-19 varied between 2.5 and $15 \%$ (Tan, Strain, 1980), metal concentrations similar to those listed in Table 3 would make a noticeable contribution to surface water concentrations particularly for $\mathrm{Fe}_{t}, \mathrm{Cu}$ and $\mathrm{Cd}$.

With the exception of silicate increases in the deep water, the changes in nutrient concentration with depth in the intermediate and deep water are relatively small and any associated changes in metal concentration would be very smail and hard to detect. Only cadmium shows a slight increase in concentration with depth and a rough covariance with phosphate or nitrate :

$\mathrm{Cd}(n \mathrm{M})=0.11 \mathrm{P}(\mu \mathrm{M})+0.19, n=10, r=0.66$.

Changes associated with silicate regeneration, similar to those predicted for nickel (Sclater et al., 1976) or copper (Moore, 1978) should be visible in Baffin Bay
Deep Water. The high concentrations of silicate in the deep water may be produced by some mechanism other than biological regeneration in the water column. In this case increases in metal concentrations may not be anticipated. On the other hand, if the silicate increases do reflect dissolution of siliceous organisms with related release of metals, then the low levels of $\mathrm{Ni}$ and $\mathrm{Cu}$ could result from some unspecified removal mechanism not previously observed in pelagic areas. The "rain" of particles resulting from the dissolution of ice may play an important role in these processes.

The iron and manganese results for samples from the intermediate and deep waters show measurable amounts of particulate iron and manganese at all depths with average particulate iron and manganese concentrations of $1.1 \mu \mathrm{gl}^{-1}$ and $0.07 \mu \mathrm{gl}^{-1}$ respectively. These measurements indicate that, unless the iron and manganese content of the particles is rather unusual, the particulate matter concentrations must be considerably higher than found at similar depths in the Atlantic Ocean. The deepest sample gives no indication of elevated metal concentrations indicating neither releases of metal from the sediments nor the existence of a bottom nepheloid layer at this station.

The distributions of trace metals in Baffin Bay and the Canadian Arctic Archipelago, both spatially and vertically, are determined principally by the metal characteristics of the inflowing water masses. The high concentration of metals in sea ice and glacier ice suggests that meltwater may also have a significant effect on surface water concentrations. No marked verticaliconcentration gradients resulting from biological activity or other geochemical processes in the water column or underlying sediments were observed.

\section{Acknowledgements}

We are grateful to A.R. Coote for the nutrient data and to J. Dalziel for careful sample collection on the 1978 cruise. J.A.C. acknowledges the financial support of the Natural Sciences and Engineering Research Council, Canada.

\section{REFERENCES}

Bailey W.B., 1956. On the origin of Baffin Bay water, J. Fish. Res. Board Can., 13, 303-308.

Bailey W.B., 1957. Oceanographic features of the Canadian Archipelago, J. Fish. Res. Board Can., 14, 731-769.

Bender M.L., Gagner C., 1976, Dissolved copper, nickel, and cadmium in the Sargasso Sea, J. Mar. Res., 34, 327-339.

Bender M.L., Klinkhammer G.P., Spencer D.W., 1977. Manganese in seawater and the marine manganese balance, Deep-Sea Res., 24, 799-812.

Bewers J.M., Macaulay I.D., Sundby B., 1974. Trace metals in the waters of the Gulf of St. Lawrence, Can. J. Earth Sci., 11, 939-950. Bewers J.M., Sundby B., Yeats P.A., 1976. The distribution of trace metals in the western North Atlantic off Nova Scotia, Geochim. Cosmochim. Acta, 40, 687-696.

Boyle E.A., Sclater F., Edmond J.M., 1976. On the marine geochemistry of cadmium, Nature (London), 263, 42-44.
Boyle E.A., Sclater F.R., Edmond J.M., 1977. The distribution of dissolved copper in the Pacific, Earth Planet. Sci. Lett., 37, 38-54.

Brooks R.R., Presley B.J., Kaplan I.R., 1967. APDĆ-MIBK extraction system for the determination of trace elements in saline waters by atomic absorption spectrophotometry, Talanta, 14, 809-816.

Bruland K.W., Knauer G.A., Martin J.H., 1978 a. Cadmium in northeast Pacific waters, Limnol. Oceanogr., 23, 618-625.

Bruland K.W., Knauer G.A., Martin J.H., 1978 b. Zinc in north-east Pacific water, Nature (London), 271, 741-743.

Bruland K.W., Franks R.P., Knauer G.A., Martin J.H., 1979. Sampling and analytical methods for the determination of copper, cadmium, zinc, and nickel at the nanogram per liter level in sea water, Anal. Chim. Acta, 105, 233-245.

Burrell D.C., 1971. Trace metal associations in sub-Arctic and Arctic marine environments, Univ. Alaska, Inst. Mar. Sci., Rep., R71-12, $119 \mathrm{p}$. 
Burrell D.C., Wood G.G., Kinney P.J., 1968. Direct spectrophotometric determination of zinc in summer Chukchi Sea waters, Trans. Am. Geophys. Union, 49, 759.

Coachman L.K., Aagaard K., 1974. Physical oceanography of Arctic and Subarctic seas, in: Marine geology and oceanography of the Arctic Seas, edited by Y. Herman, Springer-Verlag, New York.

Collin A.E., 1966. Canadian Arctic Archipelago and Baffin Bay, in: Encyclopaedia of Oceanography, edited by R.W. Fairbridge, Van Nostrand Reinhold Co., 157-168.

Collin A.E., Dunbar M.J., 1964. Physical oceanography in Arctic Canada, Oceanogr. Mar. Biol. Annual Rev., 2, 45-75.

Danielsson L.-G., 1980. Cadmium, cobalt, copper, iron, lead, nickel and zinc in Indian Ocean water, Mar. Chem., 8, 199-215.

Dyrssen D., Danielsson L.-G., Yagnar D., Mart L., 1981. Trace metals in the eastern Arctic Ocean, in: Trace metals in sea water, NATO Advanced Research Institute, Erice, Italy.

Jones E.P., Coote A.R., 1980. Nutrient distributions in the Canadian Archipelago: indicators of summer water mass and flow characteristics, Can. J. Fish. Aqu. Sci., 37, 589-599.

Mann C.R., Coote A.R., Garner D.M., 1974. The meridional distribution of silicate in the western Atlantic Ocean, Deep-Sea Res., 20, 791-801.

Moore R.T., 1978. The distribution of dissolved copper in the eastern Atlantic Ocean, Earth Planet. Sci. Lett., 41, 461-468.

Moore R.M., 1981. Oceanographic distributions of zinc, cadmium, copper and aluminium in waters of the Central Arctic, Geochim. Cosmochim. Acta, 45, 2475-2482.

Muench R.D., 1971. The physical ocenaography of the northern Baffin Bay region. The Baffin Bay - North water project, Scientific Report No. 1, Arctic Institute of North America, 150 p.
Murray J.E., 1968. The drift, deterioration and distribution of icebergs in the North Atlantic Ocean, presented at: Ice Seminar, Calgary, Alberta, conference sponsored by the Petroleum Society of C.I.M.

Redfield A.C., Friedman I., 1969. The effect of meteoric water, melt water and brine on the composition of Polar Sea water and of the deep waters of the ocean, Deep-Sea Res., 16, Suppl., 197-214.

Riis-Carstensen E., 1936. The Gotthaab Expedition, 1928. The hydrographic work and material, Medd. Groenl., 78, $105 \mathrm{p}$.

Riley J.P., Taylor D., 1972. The concentrations of cadmium, copper, iron, manganese, molybdenum, nickel, vanadium and zinc in part of the tropical northeast Atlantic Ocean, Deep-Sea Res., 19, 307-317.

Sadler H.E., 1975. The flow of water and heat through Nares Strait, Ph. D. Thesis, Dalhousie Univ.

Sclater F.R., Boyle E., Edmond J.M., 1976. On the marine geochemistry of nickel, Earth Planet. Sci. Lett., 31, 119-128.

Spencer D.W., Robertson D.E., Turekian K.K., Folsom T.R., 1970. Trace element calibrations and profiles at the Geosecs test station in the northeast Pacific Ocean, J. Geophys. Res., 75, 7688-7696.

Stefansson U., 1968. Nitrate-phosphate relationships in the Irminger Sea; J. Cons. Perm. Inter. Explor. Mer, 32, 188-200.

Strickland J.D.H., Parsons T.R., 1960. A manual of seawater analysis, Fish. Res. Board Can. Bull., 125, 203 p.

Sverdrup H.U., Johnson M.W., Fleming R.H., 1942. The oceans; their physics, chemistry and general biology, Prentice Hall Inc., 1087 p.

Tan F.C., Strain P.M., 1980. The distribution of sea ice meltwater in the Eastern Canadian Arctic, J. Geophys. Res., 85, 1915-1932. 